\title{
BANGUNAN REKREASI BERTEMAKAN ALAM-NATURAL WELLBEING RETREAT
}

\author{
Salman Airlangga ${ }^{1)}$ \\ ${ }^{1)}$ Program Studi S1 Arsitektur, Fakultas Teknik, Universitas Tarumanagara,salmanairlangga@gmail.com
}

Masuk: 14-07-2020, revisi: 31-07-2020, diterima untuk diterbitkan: 24-09-2020

\begin{abstract}
Abstrak
Bangunan Rekreasi Bertemakan Alam-Natural Wellbeing Retreat hadir untuk membantu kehidupan serta menjawab kebutuhan masyarakat yang dinamis melalui tema yang akan diangkat berupa Natural Wellbeing Retreat yang ditujukan untuk menjawab masalahmasalah utama kawasan Sunter seperti tingginya tingkat stres, kurangnya ruang terbuka hijau, dan banyaknya pensiunan menggunakan metode desain berbasis pola dengan memperhatikan obyektifitas ruang dan tapak. Natural Wellbeing Retreat dapat diartikan sebagai suatu tindakan untuk kembali ke alam agar bahagia dan sehat. Kami membutuhkan suatu rekreasi atau waktu istirahat dari segala rutinitas dan kesibukan yang dituntutkan pada mereka. Waktu rekreasi/istirahat ini bisa mengarah kepada pertemuan antar manusia-manusia kreatif dan membangun komunitas yang lebih inovatif serta produktif. Maka dari itu diambillah tema wellbeing dimana seluruh program akan disuntikan tema ini dengan tujuan utama proyek yaitu menjaga kesehatan mental, fisik, serta emosional para penggunanya dengan juga menerapkan aspek natural yang berkaitan dengan gardens/parks yang efektif untuk menciptakan komunitas yang lebih bahagia dan juga sesuai dengan lokasi terpilh yang kekurangan area terbuka hijau. Faktor alami ini akan terlebih lagi didukung dengan adanya latar belakang Danau Sunter sebagai ruang terbuka biru.
\end{abstract}

Kata Kunci: Alam; Pensiunan; Rekreasi; Stres

\begin{abstract}
Nature Themed Recreational Building-Natural Wellbeing Retreat is designed to help fulfill the daily and dynamic needs of the people through a natural concept focused on wellbeing that is aimed to answer the problems of the Sunter district such as high levels of stress, low amount of green open spaces, and the abundance of the retiree using a Pattern-Based method with the main focus being the space and site. Natural Wellbeing Retreat can be interpreted as an action to return to nature to replenish happiness and health. Humans require recreation and rest from daily routines and business forced upon them. Recreation/rest time can lead to a meeting between creative humans to build a more innovative and productive community. Therefore a wellbeing theme is taken where all the programs will be injected with the primary objective of the project, which is to maintain the mental, physical, and emotional health of its users by also applying natural aspects related to gardens/parks which are useful in creating a happier community which is also by a selected location that lacks green open areas. This natural aspect will be further supported by the background of Lake Sunter as a blue open space.
\end{abstract}

Keywords: Nature; Recreation; Retiree; Stress

\section{PENDAHULUAN}

\section{Latar Belakang}

Bersamaan dengan kesempatan dan inovasi perkembangan jaman, budaya urban saat ini pada umumnya akan memiliki sifat individualistis. Orang-orang yang seharusnya berupa mahluk sosial yang membutuhkan interaksi dan sosialisasi, dengan segala kemajuan teknologi mereka, menjadi semakin egois dan tampaknya tidak membutuhkan sesamanya. Kondisi perkotaan 
sekarang juga menjadi lebih fungsional, di mana ini membuat penduduk hanya bekerja atau melakukan praktek utilitarian terlepas dari komponen penting lainnya, misalnya, sosialisasi dengan orang-orang yang dekat. Richard Florida dalam bukunya yang berjudul "The Rise of the Creative Class" juga merujukkan bahwa setiap orang adalah individu yang kreatif dan individu yang imajinatif dan membutuhkan cara-cara inovatif pula untuk mengurangi tingkat stress, seperti menuju pusat kebugaran, yoga atau hal-hal lain. Sampai sekarang juga hal ini berlaku, namun dengan segala kelelahan yang diakibatkan kondisi hidup urban, sudah menjadi semakin inklusif menjadi kegiatan-kegiatan yang individualis (Florida, 2012) (Montgomerry, 2013).

\section{Rumusan Permasalahan}

Masalah-masalah sosial ini juga terjadi di kota Jakarta yang semakin menjadi membingungkan karena penggunaan atau penyebaran penggunaan lahan yang unik pada kawasan Sunter. Pasalnya, Sunter merupakan area yang terkenal baik sebagai kawasan hunian dan juga komersil, yang pada kasus ini banyak juga berupa industri pabrik. Contoh dari ini dapat dilihat dengan begitu banyaknya persebaran tempat kerja pada jalan-jalan utamanya. Contoh dari ini adalah banyaknya persebaran ruko pada Jalan Danau Sunter, baik itu Jalan Danau Sunter Barat, Utara, maupun Selatan yang merupakan jalan-jalan yang seolah merangkul dan memotong antara kawasan-kawasan yang kaya akan hunian (Dinisari, 2019) (Nurdiarsih, 2019).

Sunter Jaya dan Sunter Agung merupakan kawasan yang secara alami, maupun secara terpaksa akibat buruknya penataan kota, dapat menggabungkan atau mendekatkan first place maupun second place. Kemakmuran yang tidak konsisten tersebar juga menjadi suatu masalah. Ini tampak pada kawasan Sunter yang memiliki derajat kehidupan secara ekonomis yang berbedabeda, paling mudah terlihat dari kondisi rumah penduduknya. Secara teori ini dapat mengakibatkan inklusi yang lebih besar antara penduduk dengan kelas ekonomi yang berbeda. Maka dari itu, kawasan Sunter, baik itu Sunter Jaya maupun Sunter Agung harus memunculkan ide lain dan menyadarkan The Third Place bersama segala programnya sebagai suatu teori arsitektural yang dapat memberikan tempat bagi penghuni Sunter untuk saling berbaur dan bergaul satu sama lain (Dinisari, 2019) (Oldenberg, The Great, Good Place, 1997).

\section{Tujuan}

Maksud dari proyek ini adalah mengembalikan kawasan Sunter melalui The Third Place sebagai tempat untuk bergaul dan berkomunikasi dengan setiap penghuni kawasan Sunter sehingga menjadi semakin humanis, produktif, terbuka, dinamis, inventif dan selanjutnya menyadarkan kembali konsep Garden City atau lebih mengangkat aspek Garden-nya melalui ruang terbuka hijau untuk memuaskan dan sesuai dengan karakter masyarakat saat ini yang serba cepat dan dinamis (Florida, 2012) (Oldenberg, The Great, Good Place, 1997).

\section{KAJIAN LITERATUR}

\section{"The Great, Good, Place"}

The Third Place adalah tempat ketiga yang dibutuhkan oleh masyarakat selain First Place (Tempat Tinggal) dan Second Place (Tempat Kerja). Third Place memungkinkan individu untuk mengesampingkan minat dan latar belakang mereka dan pada dasarnya saling menghargai dan diskusi. Memberikan pendirian kepada sistem berbasis suara yang demokratif, ruang-ruang ini memajukan nilai sosial dengan meratakan status pengunjung, membuat kecenderungan untuk afiliasi terbuka, dan menawarkan bantuan mental kepada orang-orang dan jaringan sehingga menjadikan individu semakin humanistik dan peduli satu sama lain. Terdapat beberapa kualitas dari tempat ketiga (Oldenberg, The Great, Good Place, 1997) (Oldenberg, Celebrating the Third Place: Inspiring Stories About the Great Good Places at the Heart of Our Communities, 2001), yaitu: 
a. The Third Place as Leveler

Penghuni tempat ketiga tidak punya komitmen untuk berada di sana. Mereka tidak diamankan ke wilayah itu secara moneter, strategis, sah, atau secara umum dan diizinkan untuk melakukan perjalanan ke mana pun mereka mau.

b. The Regulars

Tempat ketiga tidak memberi arti lebih pada status seseorang di masyarakat umum. Kesejahteraan finansial atau ekonomi seseorang tidak membuat perbedaan di tempat ketiga, dengan mempertimbangkan perasaan karakteristik bersama di antara penghuninya. Tidak ada hal penting atau kebutuhan yang akan mencegah pengakuan atau kerja sama di tempat ketiga.

c. A Low Profile

Diskusi yang menyenangkan adalah titik fokus mendasar dari aktivitas di tempat ketiga, terlepas dari kenyataan bahwa itu tidak wajib menjadi tindakan utama. Nada diskusi biasanya riang dan lucu.

d. On Neutral Ground

Tempat ketiga harus terbuka dan segera tersedia untuk individu yang terlibat. Mereka juga harus mengakomodasi kebutuhan penghuninya, dan semua penghuni merasa kebutuhan mereka terpenuhi.

e. Conversation is The Main Activity

Tempat-tempat ketiga memiliki berbagai pelanggan tetap yang membantu memberi ruang ciri khas, dan membantu mengatur pola pikir dan kualitas wilayah. Pelanggan tetap pada tempat ketiga juga menarik pendatang baru, dan ada di sana untuk membantu orang lain agar merasa diterima.

f. A Home Away From Home

Tempat ketiga sangat sehat. Dalam tempat ketiga tidak ada hal berlebihan atau kepentingan diri sendiri. Tempat ketiga tidak pernah menganggap dirinya lebih dari sesungguhnya atau pretentious, dan menoleransi banyak orang, dari beberapa latar belakang yang berbeda.

g. Accessibility and Accommodation

Nada diskusi di tempat ketiga tidak pernah ditandai dengan tekanan atau getaran yang mengancam. Sebaliknya, tempat ketiga memiliki sifat yang menyenangkan, di mana diskusi yang cerdas dan obrolan konyol adalah hal yang normal, namun sangat dihargai.

h. The Mood is Playful

Penghuni tempat ketiga secara teratur akan memiliki perasaan hangat, dan kepemilikan, sama seperti di rumah mereka sendiri. Mereka merasa sedikit diri mereka didirikan di ruang tersebut, dan meningkatkan pemulihan spiritual dengan menginvestasikan energi di sana.

\section{"The Rise of the Creative Class, Revisited"}

Kreatifitas adalah kekuatan yang mendorong pengembangan ekonomi dan berubah menjadi kelas sosial yang dominan. Memahami perkembangan kelas sosial ini dan kualitasnya dapat membentuk nasib akhirnya masyarakat yang lebih baik. Awalnya individu mencari pekerjaan, namun sekarang aktivitasnya mencari individu. Ini terjadi dengan alasan bahwa individuindividu imajinatif inilah yang dapat membantu mendukung pengembangan moneter (Florida, 2012) (Glaeser, 2011).Banyak analis bisnis berpendapat bahwa pengembangan keuangan dilakukan oleh perusahaan-perusahaan. Semakin banyak perusahaan, investasi, peralatan, dan lain-lain yang dimiliki, semakin menonjol perkembangan moneter yang terjadi. Meskipun demikian, ada spekulasi moneter baru yang menyatakan bahwa bukan hanya perusahaan yang menyebabkan pengembangan keuangan, namun teknologi juga mengasumsikan pekerjaan yang signifikan dalam memajukan pengembangan moneter. Namun, tergantung pada inovasi juga tidak cukup, ada beberapa elemen berbeda, khususnya kreativitas manusia. Manusia yang memiliki skill akan mengendalikan teknologi dengan efisien, dengan tujuan bahwa itu akan 
memberikan hasil atau perkembangan keuangan yang paling maksimal. Cara untuk meningkatkan ekonomi adalah dengan mengumpulkan individu-individu yang inventif, dari negeri sendiri melainkan dari seluruh Negara (Florida, 2012) (Glaeser, 2011).

Places atau tempat, adalah hal yang paling signifikan dan mendasar dalam asosiasi moneter dan sosial. Di mana individu imajinatif memiliki sifat untuk secara konsisten menjadi dekat atau terakumulasi dengan individu inovatif dan produktif lainnya. Tempat dimana individu inventif terakumulasi akan memiliki tingkat produktifitas, opportunities, dan kehidupan yang superior. Saat ini, semua orang adalah orang yang kreatif, dan mereka membutuhkan rekreasi di luar yang dapat menyatukan mereka dengan individu kreatif lainnya. Dalam dunia kerja yang sulit, ada kalanya individu-individu ini membutuhkan tempat untuk beristirahat. Manusia membutuhkan tempat yang terbuka (open), tempat yang tidak peduli dengan etnis, jenis kelamin, usia, pekerjaan, dan arah seksual mereka. Tempat yang dapat dimanfaatkan sebagai tempat untuk melepaskan diri dari kekhawatiran mereka, sama seperti tempat untuk membingkai jaringan yang dapat mendukung setiap orang. Semua individu adalah individu yang kreatif, ujian suatu bangsa atau negara adalah membangun vitalitas daya cipta, kemampuan, dan potensi dari semua individu tersebut, dengan tujuan agar mereka dapat membangun masyarakat umum dan negara yang menciptakan, mengakui, dan memahami pentingnya keberagaman dari setiap orang (Florida, 2012) (Glaeser, 2011). Maka dari itu, sangat penting untuk menciptakan sebuah wadah yang dapat menampung orang-orang kreatif dan dapat mengembangkan kreatifitas setiap individu. Melalui hal tersebut, orang-orang dapat meningkatkan kualitas hidup mereka.

\section{"Happy City"}

Desain Urban atau pengembangan konfigurasi kota dapat memengaruhi kegembiraan atau pola pikir individu yang hidup di dalamnya. Saat ini, setidaknya ada tujuh kunci untuk membentuk "Happy City" (Montgomerry, 2013) (Gehl, 2010), termasuk:

a. Penyebaran Fasilitas

Penduduk daerah pinggiran kota perlu melakukan perjalanan panjang untuk ke sekolah, tempat berkumpul, maupun fasilitas kesehatan dan penelitian menunjukkan bahwa semakin jauh seorang individu pergi ke tempat tujuannya, semakin kurang senangnya individu itu.

b. Melarang Kendaraan Menjaga Daya Tarik Public Spaces

Kendaraan yang berlalu-lintas di sekitar wilayah terbuka menyebabkan keributan yang sangat menjengkelkan bagi lingkungan, ini membuat individu merasa tidak nyaman ketika berada di luar rumah. Dukungan area terbuka publik juga diperlukan untuk kenyamanan para pengunjung.

c. Taman yang Terpusat dengan Keberagaman Tanaman Meningkatkan Kegembiraan

Alam adalah elemen mendasar dalam setiap adegan perkotaan, komponen alam walau jumlahnya sedikit, dapat menyebabkan kondisi pikiran individu meningkat atau membaik. Penelitian menunjukkan bahwa taman kecil namun memiliki kompleksitas yang tinggi atau berbagai jenis tanaman hijau akan membuat para tamu lebih gembira.

d. Kepadatan Membuat Orang Lebih Privat

Keramaian membuat individu canggung dan memaksa mereka untuk membangun benteng agar tidak berinteraksi dengan orang lain, ini disebabkan oleh sistem sensor sentuhan orang yang mendapatkan reaksi ketika dekat dengan banyak individu. Penyamaan harus dilakukan agar tempat-tempat tidak mengalami densitas yang berlebihan.

e. Urban Design dengan Rancangan yang Memikirkan Perubahan Masa Depan Dalam proses penataan perkotaan ataupun masalah-masalah yang berkaitan dengannya, harus ada pemilihan pengaturan dengan juga merenungkan apa yang akan datang. Misalnya, agar penyumbatan tidak terjadi, perancang membuat lebih banyak jalan raya 
namun dalam kenyataannya, individu justru membeli lebih banyak kendaraan dan tetap saja menghasilkan penyumbatan.

f. Transortasi Alami Secara Fisik Meningkatkan Kegembiraan

Berjalan kaki ataupun bersepeda memberikan kegembiraan tanpa harus terjebak dalam kemacetan. Ketika terdampar di kemacetan jam sibuk, tubuh manusia mengeluarkan hormon stres yang membuat imun tubuh maupun sirkulasi darah melemah. Kota yang layak harus memiliki portabilitas yang baik, dengan juga menyediakan area khusus pejalan kaki yang nyaman dan aman maupun jalur sepeda.

g. Urban Planning yang Mengutamakan yang Kurang Beruntung

Program hari bebas kendaraan, jalur transportasi cepat, jalur sepeda yang bagus dan lalu lintas yang berkurang merupakan program yang menghasilkan penduduk yang lebih ceria, terutama untuk individu yang kurang mampu untuk membeli mobil dan semacamnya.

Ruang terbuka di daerah perkotaan saat ini seperti yang sekarang sangat tidak nyaman karena area yang kecil dan pengunjung terlalu ramai, kendaraan-kendaraan bermotor yang mengganggu kenyamanan dan juga area-area publik kurang terawat. Daerah perkotaan saat ini harus memajukan metode transportasi yang ramah lingkungan dan produktif, dan juga ruang terbuka yang menyenangkan sehingga penghuni kota bisa lebih bahagia dan semakin bergaul dengan orang lain (Montgomerry, 2013) (Gehl, 2010).

Dari teori-teori di atas, dapat dipastikan bahwa The Third Place menurut Ray Oldenburg dan Richard Florida adalah tempat yang sama pentingnya dengan tempat pertama (tempat tinggal) dan tempat kedua (tempat kerja) dimana individu-individu bukan sekedar saling berhubungan satu sama lain dan namun juga diskusi dan berkolaborasi secara inovatif dan mengurangi stres. Menurut Charles Montgomerry, ruang terbuka yang layak adalah ruang terbuka yang terbebas dari kendaraan.

\section{METODE}

\section{Metode Desain}

Metodologi desain untuk tugas ini adalah strategi yang dipelopori oleh Arsitektur RAW yang merupakan perbaikan dan penilaian untuk hipotesis yang ditemukan oleh Plowright di mana hipotesis berbasis diandalkan (Hidayat, 2019), misalnya:

a. Pattern based hypothesis: Adalah strategi untuk penataan tergantung pada bentuk dan potongan massa. Teknik ini adalah strategi yang paling bijaksana untuk memandang obyektifitas sebagai lawan ruang, tetapi melarang perspektif abstrak, misalnya, masyarakat dan budaya.

b. Force based hypothesis: Adalah teknik untuk perencanaan yang bergantung pada perspektif sosial dan budaya. Teknik ini mempertimbangkan semua perspektif yang berdampak pada pengaturan rencana termasuk keadaan manfaat, struktur, bahan, masyarakat dan lain-lain.

c. Concept based hypothesis: Adalah teknik yang meninggalkan prosedur rencana dari cara berpikir teoretis, misalnya, analogi, perumpamaan, pertanyaan alami, dan lain-lain.

Dalam mendesain RAW, melanjutkan dengan hipotesis ini menjadi teknik standar dan umum yang semakin progresif. Dalam strateginya, RAW sekali lagi mengurangi masing-masing dari tiga macam teknik Plowright untuk:

a. Pattern Based hypothesis: Terdiri dari dua bagian khususnya tidak memihak dan ilustratif. Kedua struktur ini dapat dipilih menjadi alasan untuk melihat jenis struktur seperti yang direncanakan.

b. Force based hypothesis: Terdiri dari tiga bagian, khususnya adat, modern, dan campuran (serbaguna). Ini dapat digunakan untuk memadukan komponen pengaturan sosial-sosial dan penciptaan dalam struktur. 
c. Concept based hypothesis: Terdiri dari dua bagian, gua dan rumah. Gua adalah alternatif yang digunakan.

Hipotesis yang akhirnya digunakan adalah pattern based hypothesis, atau hipotesis berbasis pola, dengan lebih memperhatikan obyektifitas ruang dan tapak dengan memperhatikan kawasan sebagai sumber segala isu-isu yang ingin ditanggapi dan juga penduduk sekitar dengan kepribadian fundamental mereka terlebih lagi dibandingkan dengan budaya-budaya yang diterapkannya.

\section{DISKUSI DAN HASIL}

\section{Latar Belakang Pemilihan Kawasan}

Kriteria pemilihan tapak yang memiliki masalah-masalah seperti memiliki luas RTH yang rendah dan memiliki jumlah pensiunan yang tinggi, yaitu:

a. Kawasan dengan Tingkat Stres yang Tinggi

Stres berkaitan dengan tingkat kebahagiaan orang yang tinggal dalam kawasan tersebut, jika tingkat stres yang tinggi terjadi maka kebahagiaan, kepuasan, produktifitas, maupun kegiatan sosialisasi seseorang akan menjadi terganggu. Stres dipengaruhi oleh beberapa macam faktor, antara lain faktor ekonomi maupun faktor keadaan lingkungan. Faktor ekonomi dapat berupa permasalahan dengan tempat pekerjaan, permasalahan intensitas pengunjung yang mengunjungi dagangan, dan lain-lain. Faktor keadaan lingkungan dapat berupa keadaan kemacetan lalu lintas (terdapat dalam buku "Happy City") yang dapat mempengaruhi keadaan psikis seseorang, maupun ruang terbuka publik yang kurang memadai. Faktor-faktor ini terlihat pada kawasan terpilih, kawasan Sunter, yang memiliki tingkat kemacetan, kepadatan, dan aktivitas yang tinggi sebagai area komersil dan juga hunian dengan tingkat ekonomi penghuni yang beragam.

b. Kawasan dengan Jumlah Ruang Terbuka Hijau yang Rendah

Undang-Undang Nomor 26 Tahun 2007 tentang Penataan Ruang telah memerintahkan bahwa jumlah ruang hijau kota harus minimal 30 persen dari seluruh wilayah kota sementara di Jakarta, wilayah ruang hijau terus menurun sejak kedekatannya. naik tinggi dan mal. Juga, selama dua dekade terakhir, kambuhnya perkembangan permukiman ilegal di berbagai wilayah yang tidak benar-benar diusulkan untuk lahan pribadi telah berkembang. Kepala Dinas Kehutanan DKI Jakarta Suzi Marsitawati mengatakan bahwa saat ini pengembangan Ruang Terbuka Hijau (RTH) baru mencapai 9,9 persen. Jakarta Utara dan Jakarta Barat memiliki jumlah taman kota dan lingkungan paling sedikit dengan luas RTH paling kecil. Namun karena tidak tersedia cukup data untuk menentukan kelurahan apa yang memiliki jumlah dan luas RTH paling rendah diantara kedua kotamadya tersebut, data jumlah pensiunan digunakan untuk penyaringan tahap berikutnya.

c. Kawasan dengan Jumlah Pensiunan yang Tinggi

Jumlah penduduk di DKI Jakarta pada 2019 diperkirakan mencapai 10,5 juta. Angka ini meningkat 0,73\% dari populasi yang diantisipasi pada 2018 dari 10,4 juta orang. Populasi wanita habis-habisan di Jakarta adalah 5,3 juta sedangkan populasi pria adalah 5,2 juta. Sementara itu, jumlah penghuni pensiun yang berada dalam cakupan usia 55 tahun dan lebih dari 1.208 .890 orang atau 11,5 persen dari penduduk Jakarta. Sangat mengherankan bahwa 7 dari 10 pensiunan di Indonesia memiliki masalah pengeluaran yang disebabkan oleh banyak hal, salah satunya tidak memiliki rencana anuitas. Hanya sekitar 9 persen individu yang hidup dengan baik di masa pensiun. Lebih dari 18 persen orang kembali bekerja di masa pensiun untuk memenuhi kebutuhan terkait uang tunai mereka dan 73 persen jaringan harus bergantung pada orang lain, misalnya, anak-anak dan kerabat mereka. Menyinggung informasi, tidak mengherankan bahwa sampai sekarang banyak pensiunan didesak untuk kembali bekerja seperti spesialis di usia mereka yang tidak menguntungkan. 
Sunter Agung menjadi kelurahan pilihan dimana tapak akan dipilih dan proyek akan dibangun. Melihat tema dan ide yang sudah dipilih dan dipikirkan dengan matang, kelurahan ini menjadi tempat yang paling cocok untuk dibangunnya proyek Natural Wellbeing Retreat terlebih lagi program Community Garden and Market berdasarkan analisa data yang sudah dilakukan. Namun setelah melihat lokasi, tapak lebih tepat lagi berada pada kawasan sekitar Danau Sunter yang berada pada kelurahan Sunter Jaya dengan alasan ingin dimanfaatkannya keindahan dan status sebagai kawasan rekreasi danau tersebut. Karena Sunter Jaaya juga memiliki jumlah pensiunan yang tinggi, 3.336 jiwa dibandingkan Sunter Agung dengan 4.194 jiwa, maka kawasan ini masih memenuhi kriteria. Karena Tapak berada pada ujung Sunter Jaya dan sangat mendekati Sunter Agung maka dampaknya tetap akan terasa oleh Sunter Agung sehingga analisa yang dilakukan harus dilakukan pada kedua kelurahan.

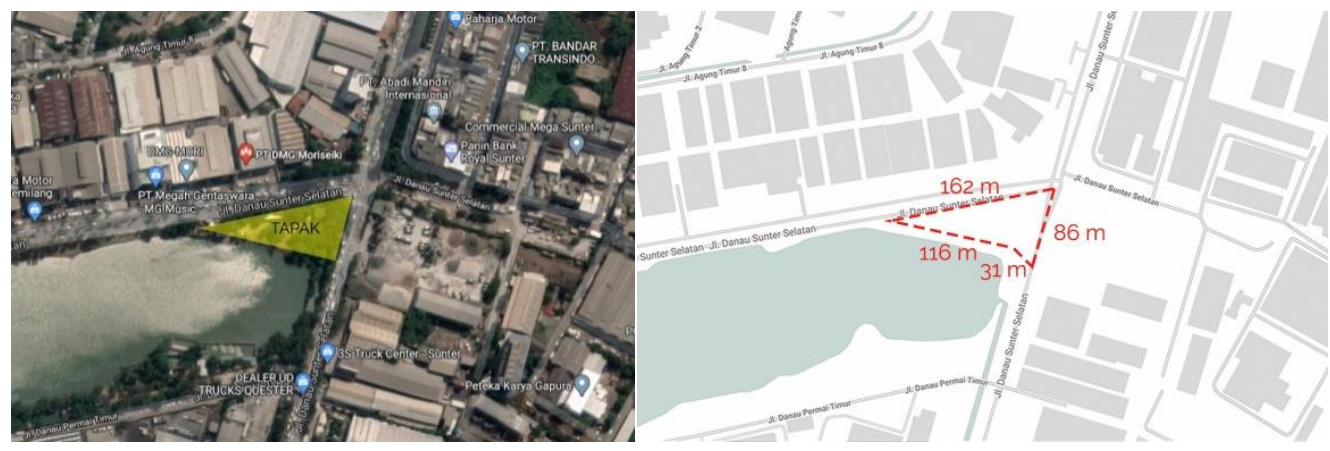

Gambar 1. Lokasi Tapak

Sumber: https://www.google.com/maps (Diakses pada 20 Februari 2020)

Kawasan sekitar Danau Sunter sudah bagai menjadi pusat kehidupan bagi kedua kelurahan Sunter Jaya dan Sunter Agung dengan suatau pemandangan alam yang menarik dan menyegarkan terlebih di kawasan tersebut yang terkenal dengan pabrik-pabriknya sebagai kawasan industri. Kawasan ini sudah dikenal sebagai area rekreasi dengan banyak pengunjung yang dating untuk menikmati restoran dan café yang tersedia ataupun bahkan hanya sekedar "menongkrong" dan memancing. Kawasan ini diapit oleh area-area hunian dengan jenis-jenis yang berbeda pula. Terdapat banyak perumahan baik dengan kelas menengah-keatas maupun kebawah. Apartemen-apartemen pun terdapat. Kelurahan Sunter Jaya dan Sunter Agung juga tidak dikenal sebagai kawasan berjalan utama macet dengan Jalan Danau Sunter Selatan sebagai akses utama ke tapak yang memiliki lalu lintas yang cukup baik.

\section{Analisis Program Kegiatan}

The Third Place hadir untuk membantu kehidupan serta kebutuhan masyarakat yang dinamis ini melalui tema yang akan diangkat berupa Natural Wellbeing Retreat. Melalui analisa tentang para pengguna beserta aktivitas dan kebutuhan mereka di kawasan Sunter, berikut merupakan program-program yang dipilih:

\section{Public Pavilion}

Pada base atau podium proyek terdapat zoning Public Pavilion dimana pengunjung dapat melakukan kegiatan seperti memancing pada kolam-kolam ikan yang tersedia, menggunakan perahu pada deck-deck, menikmati water fountain dan juga nonton bareng di ampiteater. Open area ini akan menjadi area yang paling menjiwai Third Place karena memiliki aktivitas utama yaitu engagement dimana area communal ini akan menjadi pusat pertemuan dan perbincangan sambil menikmati suasana alami walau dapat digunakan untuk aktivitas sekunder seperti mengerjakan tugas, berduduk-dudukan, dan menikmati makanan. Area ini juga akan mengakomodasi acara-acara seperti perayaan, lomba, maupun pergelaran dengan tujuan mendatangkan orang-orang yang belum menjadi regulars pada proyek ini. 


\section{Natural Retreat Area}

Mengingat kawasan Sunter tinggi akan jumlah ruko dan perkantoran, Natural Retreat Area akan menanggapi begitu banyaknya pekerja yang kekurangan aktivitas fisik. Disini pengunjung dapat menikmati alam melalui tanaman-tanaman dan juga pohon-pohon masif yang memberikan kesan berada di hutan. Pada lantai dasar pengjung dapat melakukan piknik, camping sementara, dan juga berolahraga. Akan ada area-area yang akan digunakan untuk bercocok tanam namun hanya untuk bunga (tanaman sayuran dan buah-buahan aka nada pada Community Garden). Area ini juga dapat digunakan untuk aktivitas sekunder seperti mengerjakan tugas, berduduk-dudukan, dan menikmati makanan. Area ini akan menjadi pusat dari proyek dimana aspek-aspek gardens/parks sesuai dengan apa yang dikatakan Charles Montgomery dalam bukunya Happy City dimana penyediaan alam dapat menyebabkan kondisi pikiran individu meningkat atau membaik. Dengan menyediakan tempat untuk olah raga dan menikmati alam, area ini diharapkan dapat membugarkan fisik pengunjung sekaligus mental mereka.

\section{Commercial Area}

Commercial Area adalah salah satu program yang paling menguntungkan bagi proyek, bukan sekedar sebagai wadah income namun juga sebagai daya tarik yang mutlak. Area ini berisi Food Center dan Market. Setiap orang membutuhkan makanan, namun pada kawasan Sunter, pusat kuliner bagaikan terbelah secara kelas antara menengah-kebawah atau sekalian mengarah kepada elitist. Ini tampak dengan banyaknya warung makan sederhana dan restoran ataupun pusat kuliner yang tidak terjangkau. Tidak ada pusat kuliner yang bisa dinikmati bersama maka dari itu, program ini ditujukan sebagai pengisi pasar tersebut. Ditambah lagi dengan sudah begitu banyaknya warung-warung yang dibangun pada area tapak seolah ingin mengkapitalisasikan keindahan Danau Sunter yang mendukung alasan keberadaannya program ini. Food Center juga akan terhubung dengan area nonton bersama atau "Nobar" agar pengunjung yang tidak tertarik pada aktivitas fisik yang disediakan proyek, contohnya golongan pengunjung yang sudah terlalu lelah dan hanya ingin menikmati minuman hangat seperti pekerja pabrikan, ini dapat bersantai dan menikmati kebersamaan sambil terhibur tayangan. Diharapkan bahwa tayangan tersebut dapat mengumpulkan orang-orang dengan ketertarikan yang sama dan mendorong mereka untuk bersosialisasi. Market sendiri akan menjadi pendukung dari community garden sebagai tempat penjualan buah dan sayuran yang dihasilkannya. Market juga akan memberikan manfaat capital atau keuangan dengan memberikan diskon bagi orang yang bekerja. Tentunya semua akan diatur dengan sistem dan hanya penghuni kelurahan yang boleh ikut mengambil bagian dari diskon tersebut agar proyek tidak menjadi tempat kerja atau second place.

\section{Community Garden}

Community Garden menggunakan petak individu atau bersama yang dibudidayakan oleh sekelompok orang di lahan pribadi atau terbuka sambil menghasilkan produk organik, sayuran, serta tanaman yang dikembangkan untuk keperluan mereka. Di seluruh dunia, kebun masyarakat dapat memenuhi berbagai macam tujuan, misalnya, peningkatan estetis komunitas, kesejahteraan fisik atau mental, atau pelestarian tanah. Community Garden pada proyek akan menjadi area aktivitas sekunder dengan berbagai macam manfaat bagi warga, khususnya para pensiunan yang kekurangan aktivitas akibat ketidakmampuan untuk kembali bekerja. Dengan ini, proyek akan memberikan manfaat lebih dari sekedar spiritual tonic atau social gathering dengan menawarkan aktivitas yang membugarkan mental dan fisik. 


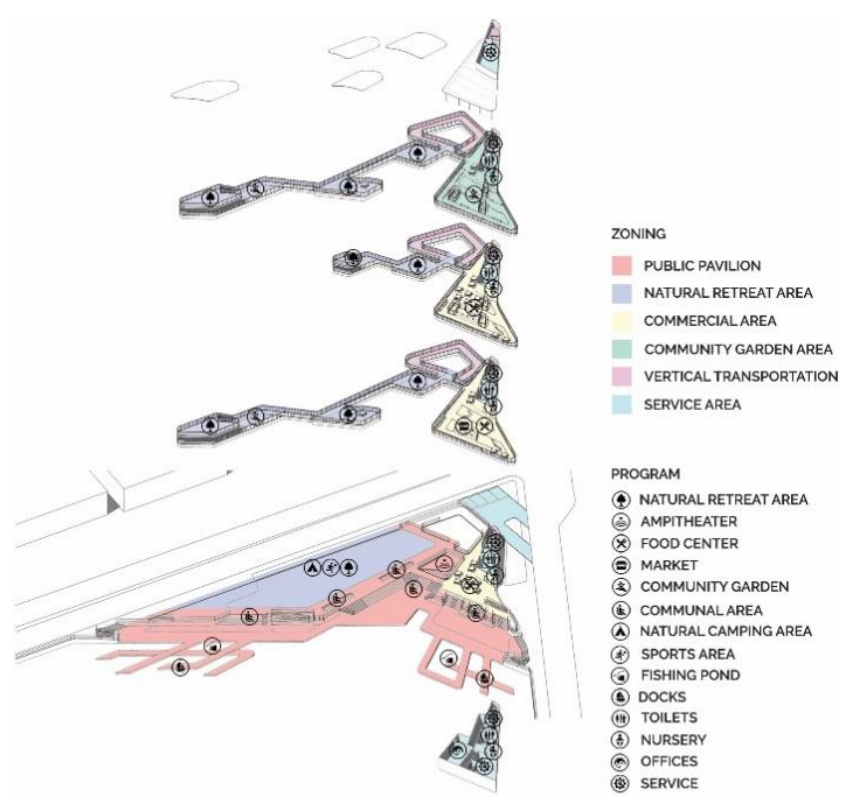

Gambar 2. Zoning dan Program

Sumber: Penulis, 2020.

\section{Analisis Konsep dan Bentuk Rancangan}

Berikut analisis tapak yang berpengaruh pada pembentukkan massa dengan aspek yang paling berpengaruh berupa view dan orientasi. View yang baik hanya menghadap danau serta orientasi utama akan lebih fokus pada kedua jalan yang mengapit tapak.
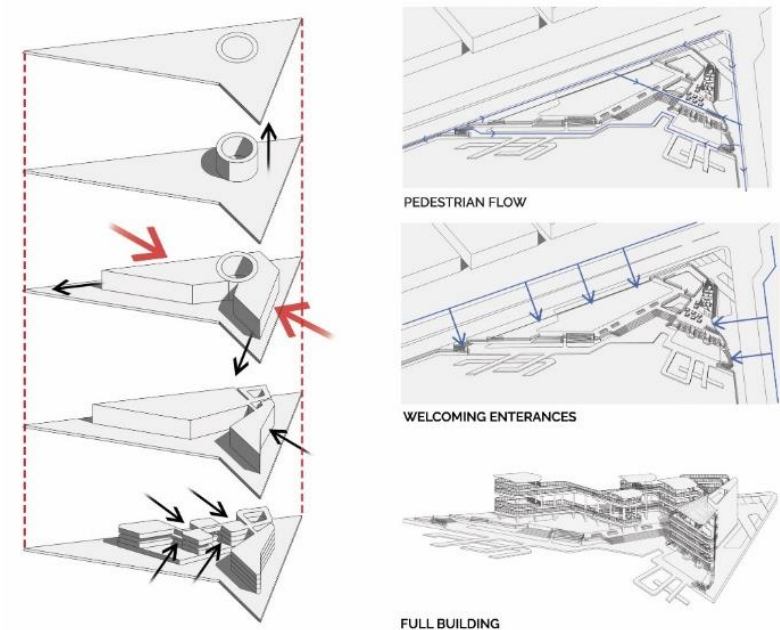

Gambar 3. Diagram Proses Gubahan Massa

Sumber: Penulis, 2020.

Massa diawali dengan peletakkan ramp pada ujung tapak. Ramp ditingkatkan untuk mencapai keempat lantai sebagai transportasi utama proyek. Dua cabang ditarik dari ramp untuk berorientasi pada kedua jalan utama. Kemudian massa dimodifikasi kembali dan ujung-ujung yang lancip di lengkungkan. Akhirnya, cabang kiri diberi cekungan-cekungan agar bisa ditembus oleh pohon-pohon. Ini dilakukan agar pengunjung dapat menikmati alam melalui pohon-pohon masif yang memberikan kesan berjalan melalui hutan namun bukan sekedar pada ground floor melainkan lantai-lantai atas juga sehingga diharapkan memberikan pengalaman yang unik dan berbeda. Podium dirancang untuk memberikan alur tembus tapak antara kedua jalan pengapit sehingga dapat menarik perhatian pejalan kaki yang hanya sekedar lewat. Alur keluar masuk dioptimalkan untuk meningkatkan permeabilitas. 
Pada podium proyek terdapat zoning Public Pavilion dimana pengunjung dapat melakukan kegiatan seperti memancing pada kolam-kolam ikan yang tersedia, menggunakan perahu pada deck-deck, menikmati water fountain dan juga nonton bareng di ampiteater. Ini dimaksudkan untuk mendorong pertemuan antar sesame pengunjung dengan kegemaran/hobi yang sama sehingga meningkatkan kolaborasi. Pada kiri bangunan terdapat Natural Retreat Area dimana pengunjung dapat datang bersama maupun sendiri untuk menikmati alam melalui tanamantanaman dan juga pohon-pohon masif yang memberikan kesan berada di hutan. Pada lantai dasar pengjung dapat melakukan piknik, camping sementara, dan juga berolahraga. Pada lantai dua, tiga, dan empat terdapat area yang dapat digunakan untuk bercocok tanam namun hanya untuk bunga. Juga terdapat mezzanine-mezanine yang diharapkan dapat meningkatkan efisiensi ruang dan pemanfaatan view pada pohon-pohon dan danau. Ini semua dimaksudkan untuk memberikan ruang terbuka hijau yang luas dan terpusat bagi penghuni kawasan Sunter yang, sesuai teori Charles Montgomery, akan meningkatkan kesehatan mental pengunjung.

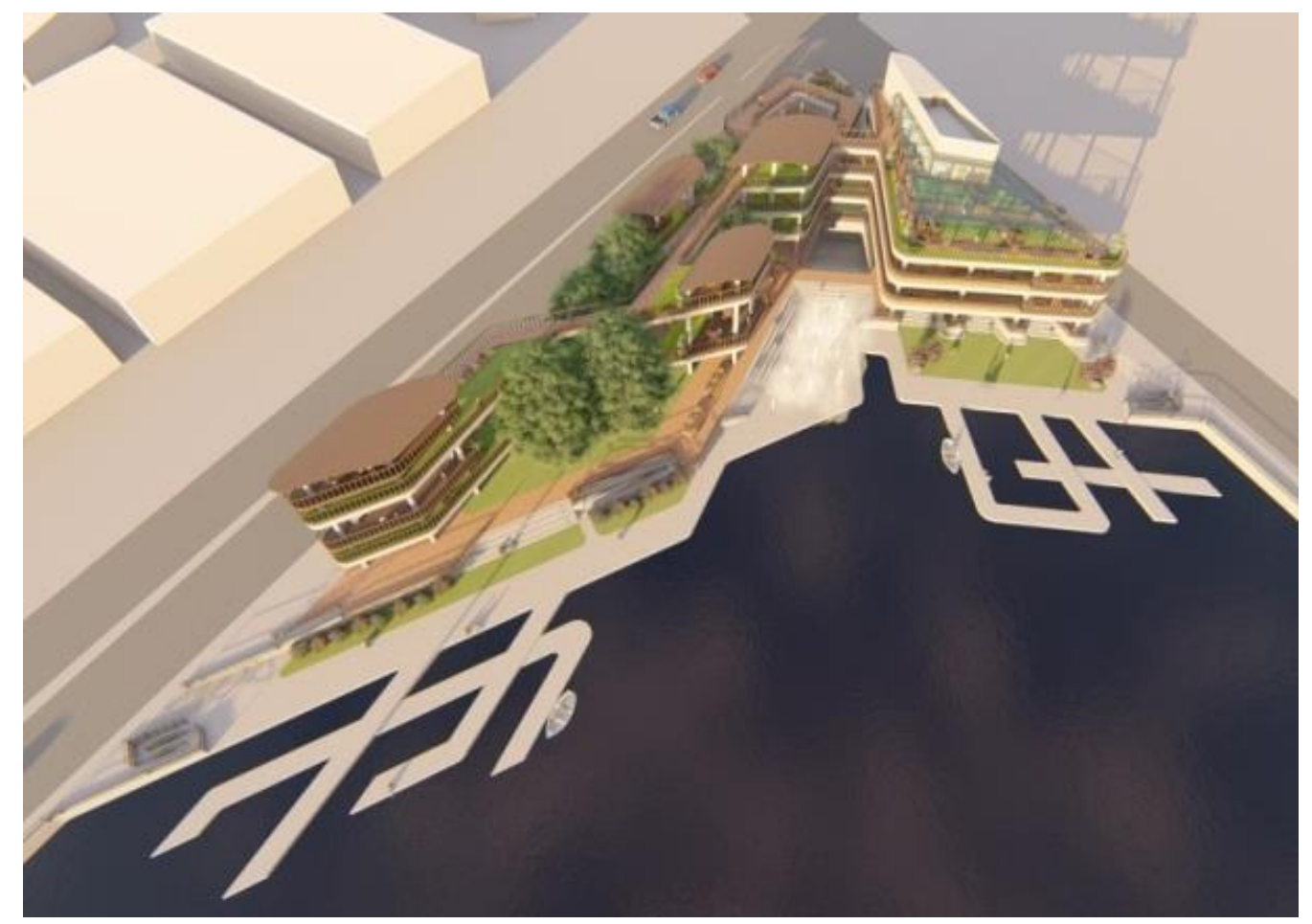

Gambar 4. Gambar Visualisasi Proyek

Sumber: Penulis, 2020.

Pada kanan bangunan terdapat Commercial Area dimana pengunjung dapat membeli makanan, pada Food Center, ataupun hasil Community Garden. Pada lantai empat terdapat Community Garden dimana tanaman seperti sayuran dan buah-buahan dapat ditumbuhkan secara optimal. Terdapat void-void dimana cahaya alami dapat menembus dan mencapai bunga-bunga yang tertanam pada Food Center. Void-void ini pun terlindungi dari derasnya hujan dengan adanya atap kaca tempered untuk menghindari kebanjiran pada lantai dua dan tiga. Penyiraman bunga-bunga maupun Community Garden dilakukan oleh sprinkler. Diingatkan Kembali bahwa orang yang mengambil bagian dalam bercocok tanam pada Community Garden akan mendapatkan diskon pada Market. Peraturan dan jadwal akan ditentukan oleh pihak administrasi. Ramp-ramp menjadi bagian penting proyek mengingat bahwa third place harus bisa dinikmati semua orang termasuk lansia, mengingat bahwa salah satu isu yang diangkat adalah banyaknya pensiunan yang menghuni Kawasan Sunter, dan juga orang difabel. Sirkulasi vertikal utama pun berupa ramp dengan kemiringan yang sesuai standar ramp sehingga dapat ditanjak, bahkan, oleh pengguna kursi roda. 


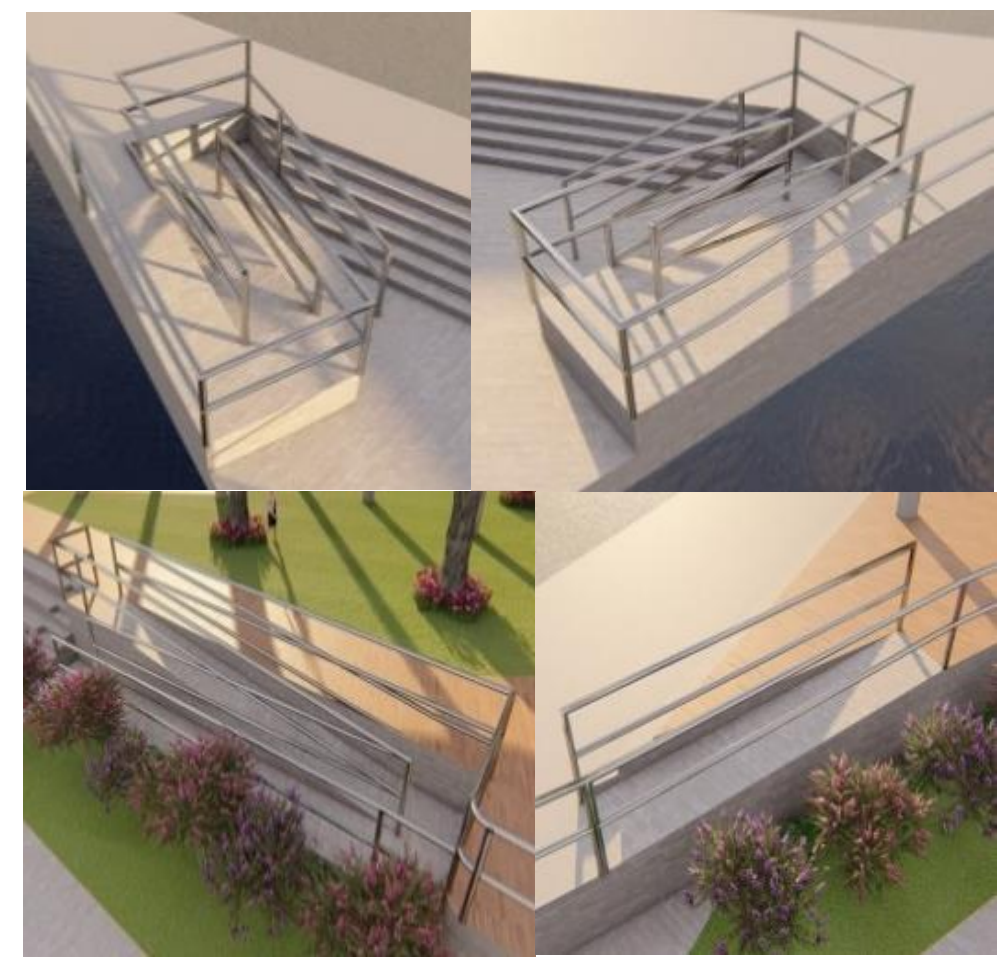

Gambar 5. Ramp Sebagai Sarana Sirkulasi Vertikal pada Proyek Sumber: Penulis, 2020.

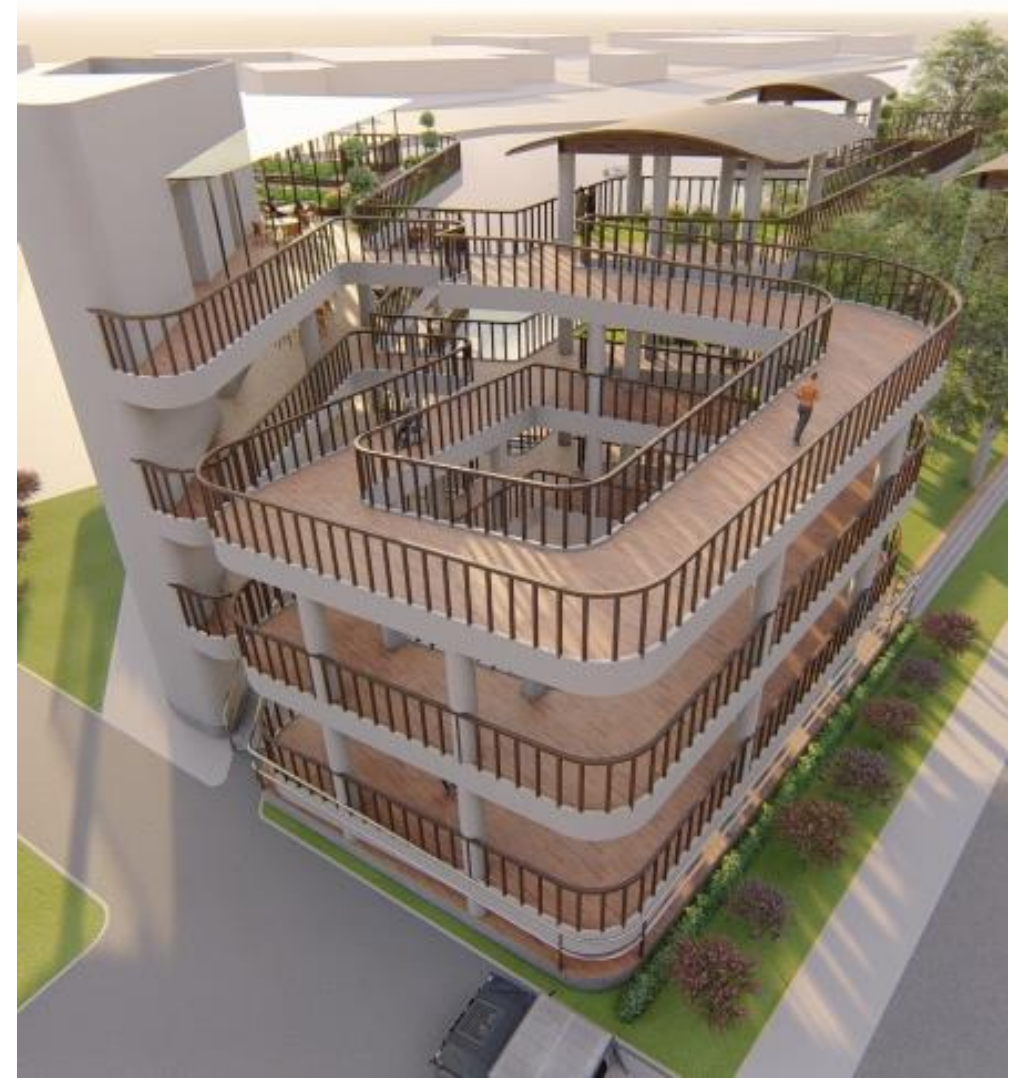

Gambar 6. Ramp Utama Bangunan

Sumber: Penulis, 2020. 


\section{KESIMPULAN DAN SARAN}

The Third Place adalah tempat yang sama pentingnya dengan tempat pertama (tempat tinggal) dan tempat kedua (tempat kerja) dimana individu-individu bukan sekedar saling berhubungan satu sama lain dan namun juga diskusi dan berkolaborasi secara inovatif dan mengurangi stres. Ruang terbuka yang layak adalah ruang terbuka yang terbebas dari kendaraan. Natural Wellbeing Retreat dapat menyajikan suatu wadah perkumpulan dan rekreasi yang dapat meningkatkan inovasi, kolaborasi, dan kesehatan mental pengunjung serta menjawab isu-isu unik kawasan Sunter melalui program-program yang tersedia.

\section{REFERENSI}

Dinisari, M. C. (2019, Februari 25). Ini Sejarah dan Mitos Danau Sunter Jakarta. Retrieved Februari 2020, 20, from KABAR24: https://kabar24.bisnis.com/read/20180225/79/742769/ini-sejarah- dan-mitos-danausunter-jakarta

Florida, R. (2012). The Rise Of The Creative Class. New York: Basic Books. Gehl, J. (2010). Cities for People. Washington: Island Press.

Glaeser, E. L. (2011). Triumph of the City: How Our Greatest Invention Makes Us Richer, Smarter, Greener, Healthier and HappierEdward L. Glaeser. London: Penguin Press.

Hidayat, A. (2019). Methodgram. Jakarta: AW Press.

Jayani, D. H. (2019, September 10). Jumlah Penduduk DKI Jakarta 2019 Mencapai 10,5 Juta Jiwa. Retrieved Februari 20, 2020, from Katadata: https://databoks.katadata.co.id/datapublish/2019/09/10/jumlah-penduduk-dki-jakarta2019-mencapai-105-juta-jiwa

Meilanova, D. R. (2017, Oktober 30). Dirut Taspen, Jumlah Pensiunan dan Peserta Baru Tak Seimbang. Retrieved Februari 20, 2020, from Bisnis: https://finansial.bisnis.com/read/20171030/215/704336/dirut-taspen-jumlah-pensiunandan-peserta-baru-tak-seimbang

Montgomerry, C. (2013). Happy City. Canada: Farrar.

Novelino, A. (2019, Oktober 18). Target Masih Jauh, DKI Ingin Swasta Sumbang 10 Persen RTH. Retrieved Februari 20, 2020, from CNN Indonesia: https://www.cnnindonesia.com/nasional/20191017195256-20-440515/target-masih-jauhdki-ingin-swasta-sumbang-10-persen-rth

Nurdiarsih, F. (2019, September 29). Sunter Tempo Dulu, Sebagian Besar adalah Rawa. Retrieved Februari 20, 2020, from Liputan 6: https://www.liputan6.com/news/read/4074391/sunter- tempo-dulu-sebagian-besaradalah-rawa

Oldenberg, R. (1997). The Great, Good Place. Cambridge: Da Capro Press.

Oldenberg, R. (2001). Celebrating the Third Place: Inspiring Stories About the Great Good Places at the Heart of Our Communities. Cambridge: Da Capo Press.

Subagio, J. (2019, Juni 27). Jakarta Masih Kekurangan Ruang Terbuka Hijau, Ini Penjelasan Ahli. Retrieved Februari 20, 2020, from Kompas: https://sains.kompas.com/read/2019/06/27/200400723/jakarta-masih-kekuranganruang- terbuka-hijau-ini-penjelasan-ahli 